\title{
Estetika Hindu Pada Segehan Manca Warna
}

\author{
Ida Ayu Tary Puspa ${ }^{1}$, Ida Bagus Subrahmaniam Saitya ${ }^{2}$ \\ ${ }^{1}$ Program Studi Industri Perjalanan Fakultas Dharma Duta \\ ${ }^{2}$ Program Studi Teologi Hindu Fakultas Brahma Widya \\ Institut Hindu Dharma Negeri Denpasar, Jalan Ratna Nomor 51 Denpasar
}

'tary_puspa@ihdn.ac.id

\begin{abstract}
Keindahan (estetika) hasil dari kreativitas manusia baik sengaja atau tidak, pada prinsipnya adalah untuk memenuhi kepuasan bathin atau rohani bagi pembuat karya itu sendiri dan bagi masyarakat penikmat. Kehidupan manusia dalam kesehariannya selalu memerlukan keindahan untuk memenuhi kepuasan bathinnya, baik yang diperoleh dari keindahan alami maupun keindahan karya manusia. Oleh karena itu, kahadiran karya estetika sangat dibutuhkan manusia sebagai penghalus rasa dalam kehidupannya. Estetika Hindu pada intinya merupakan cara pandang mengenai rasa keindahan (langö) yang diikat oleh nilai-nilai agama Hindu yang didasarkan atas ajaran-ajaran kitab suci Weda. Ada beberapa konsep yang kiranya menjadi landasan penting dari estetika Hindu. Konsep-konsep yang dimaksud antara lain konsep kesucian (Siwam), kebenaran (Saytam), dan konsep keseimbangan Sundaram).Segehan bila dipandang dari estetika Hindu tentunya dengan lima warna yang dimiliki yaitu putih, merah, kuning, hitam, dan brumbun akan dipersembahkan untuk keharmonian dalam kehidupan
\end{abstract}

Kata kunci: estetika Hindu, segehan manca warna

\section{Hindu Aesthetics at Segehan Manca Warna}

Beauty (aesthetics) results from human creativity whether intentionally or not, in principle, is to fulfill inner or spiritual satisfaction for the creator of the work itself and for the community of connoisseurs. Human life in its daily life always requires beauty to fulfill its inner satisfaction, both obtained from natural beauty and the beauty of human works. Therefore, the presence of aesthetic works is needed by humans as a refinement in their lives. Hindu aesthetics is essentially a way of looking at a sense of beauty (langö) which is bound by Hindu values based on the teachings of the Vedic scriptures. There are several concepts that would form an important foundation of Hindu aesthetics. The concepts in question include the concept of holiness (Siwam), truth (Saytam), and the concept of Sundaram balance). Segehan when viewed from Hindu aesthetics, of course, with five colors that are white, red, yellow, black, and brumbun will be dedicated to harmony in life

Keywords: Hindu aesthetics, segehan manca warna

Proses Review : 1 - 28 Januari 2020, Dinyatakan Lolos: 10 Februari 2020 


\section{PENDAHULUAN}

Kebudayaan Bali yang lebur dengan agama Hindu menjadi suatu kekhasan dalam Hindu di Bali, termasuk pula dalam praktik ritual keagamaan yang juga mengambil kearifan lokal dan kebiasaan masyarakat yang berasaskan desa, kala, dan patra pada daerah setempat. Hindu menjadi unik karena fleksibel dan toleran dalam praktik acara agamanya. Menurut Claire Holt dalam (Puspa, 2019b: 170) bahwa salah satu unsur budaya yang penting yang memberi nilai keindahan, keselarasan, dan keseimbangan adalah seni.

Mengenai keindahan dalam perkembangan pemikiran manusia banyak diapresiasi oleh para filsuf, budayawan, dan seniman dari zaman kuna sampai modern ini mengenai “Apakah keindahan itu?" Mortimer Adler menyebutkan sifat dari sesuatu benda yang memberi kita kesenangan yang tidak berkepentingan yang kita bisa memperolehnya semata-mata dari memikirkan atau melihat benda individual itu sebagaimana adanya. Adapun filsuf abad pertengahan Thomas Aquinas merumuskan keindahan sebagai sesuatu yang menyenangkan ketika dilihat.

Ritual merupakan ciri khas pelaksanaan kegiatan keagamaan di Bali yang memiliki makna sebagai suatu bentuk ketulusan pemberian atau persembahan kepada Sang pemberi hidup dan segala pelimpah di dunia ini. Beliau Tuhan Yang Maha Esa (Sang Hyang Widhi) dengan landasan kesucian hati dan ketulusan hati yang disebut dengan Yajña. Yajña merupakan upacara korban suci atau pengorbaan yang penuh dengan rasa hormat serta memiliki tujuan sangat mulia dan luhur dan dalam ibadah dapat dilakukan berupa persembahan yang cenderung dilaksanakan dengan pelaksanaan upacara keagamaan serta dalam hidup dilakukan dengan tindakan baik dilakukan dengan pikiran, perkataan maupun perbuatan (Puspa, 2019a:41).

Upacara di Bali yang sarat akan keindahan bentuk ragam upakara atau banten merupakan sebuah keindahan sebagai luapan rasa emosi keagamaann dan wujud terimakasih kepada Sang Hyang Widhi. Bila dilihat sepintas lalu upakara Hindu sangatlah indah karena merupakan wujud pengungkapan rasa estetis.

Termasuk pula diantaranya ialah segehan yang merupakan bentuk upakara, yaitu Bhūta Yajña yang ditujukan kepada para Bhüta yang dimaksudkan untuk nyomya, yakni penetralisasi kekuatan jahat atau lebih dimaksudkan untuk melanggengkan hubungan yang harmonis dan serasi antara sesama ciptaan Tuhan. Struktur segehan begitu indah, bukan hanya dari segi bentuk, bahan pembentuknya termasuk pula warna-warna yang memiliki makna dan pula bernilai sakral dan magis.

\section{PEMBAHASAN}

\section{Estetika dan Estetika Hindu}

Keindahan (estetika) hasil dari kreativitas manusia baik sengaja atau tidak, pada prinsipnya adalah untuk memenuhi kepuasan bathin atau rohani bagi pembuat karya itu sendiri dan bagi masyarakat penikmat. Kehidupan manusia dalam kesehariannya selalu memerlukan keindahan untuk memenuhi kepuasan bathinnya, baik yang diperoleh dari keindahan alami maupun keindahan karya manusia. Manusia tidak dapat dipisahkan dengan keindahan (estetika), karena keindahan sebagai penyeimbang logika manusia. Oleh karena itu kahadiran karya estetika sangat dibutuhkan manusia sebagai penghalus rasa dalam kehidupannya.

Ilmu estetika adalah suatu ilmu yang mempelajari segala sesuatu yang berkaitan dengan keindahan, mempelajari semua aspek dari apa yang kita sebut keindahan, (Djelantik. 2004: 9). Istilah Estetika dipopulerkan oleh Alexander Gottlieb Baumgarten (1714 - 1762) melalui beberapa uraian yang berkembang menjadi ilmu tentang keindahan. (Encarta Encyclopedia 2001, 1999). Baumgarten menggunakan istilah estetika untuk membedakan antara pengetahuan intelektual dan pengetahuan indrawi. Dengan melihat bahwa istilah estetika baru muncul pada abad 18, maka pemahaman tentang keindahan sendiri harus dibedakan dengan pengertian estetik.

Menurut Dibia (2003:94) dalam Yudha Triguna, Agama Hindu merupakan unsur paling dominan sekaligus roh budaya Bali. Agama Hindu adalah sumber utama dari nilainilai budaya yang menjiwai kebudayaan Bali. Setiap hasil kreativitas budaya Bali, termasuk kesenian, tidak akan bisa lepas dengan ikatan nilai-nilai luhur budaya Bali, terutama nilai-nilai estetika yang bersumber dari agama Hindu.

Kesucian (siwam) pada intinya menyangkut nilai-nilai ketuhanan yang juga mencakup Yajña dan taksu. Umat Hindu, seperti yang terlihat di Bali, memiliki pandangan estetik yang diikat oleh nilai-nilai spiritual ketuhanan sesuai dengan ajaran agama Hindu. Kebenaran (satyam) mencakup nilai kejujuran, ketulusan, dan kesungguhan. Keseimbangan (sundaram) yang mencakup persamaan dan perbedaan dapat terefleksi dalam beberapa dimensi.

\section{Analisis Estetika pada Segehan Manca Warna}

Dilihat dari pengertian estetika di atas sangatlah tidak berlebihan apabila segehan manca warna bila disebut indah terlebih lagi apabila dilihat pada sisi pengamat seni itu. Tidak hanya sekedar indah tetapi juga sarat dengan makna dan terlebih lagi bahwa estetika Hindu komplit dengan Shiwam, Satyam dan Sundaram.

Sesuatu dapat dikatakan indah apabila mengandung unsur-unsur estetika, yakni (1) Wujud atau rupa (appearance) yang meliputi bentuk (form) atau unsur yang mendasar dan susunan atau struktur, (2) Bobot atau isi (substance) yang meliputi suasana (mood), gagasan (idea), dan pesan (message), dan (3) Penampilan, penyajian (presentation) 


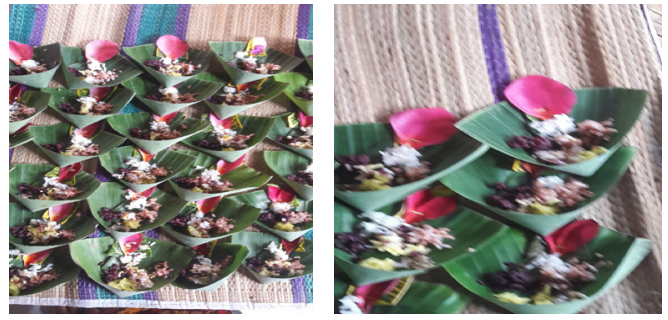

Gambar 1. dan Gambar 2. Struktur Segehan Manca Warna (Dokumen Puspa, 2020)

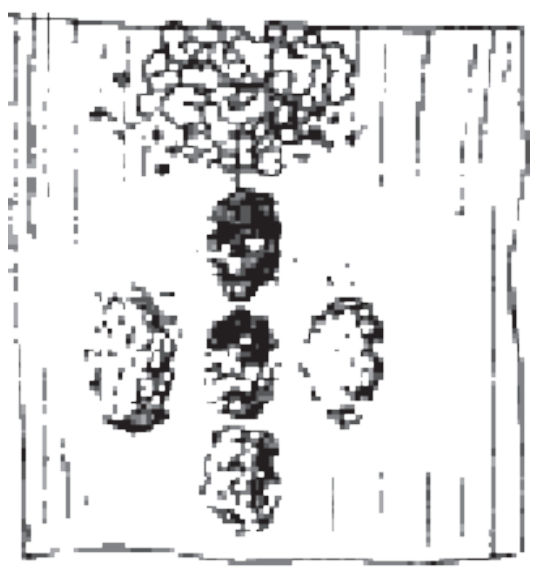

Gambar 3. Ilustrasi Segehan manca warna

yang meliputi bakat (talent), Ketrampilan (skill), dan sarana atau media, (Djelantik. 2004:17).

\section{Struktur dan Bahan Segehan Manca warna}

Bhuta Yajña berasal dari kata Bhuta yang berarti unsur-unsur alam yang telah diadakan, dan Yajña yang berarti persembahan yang tulus ikhlas, jadi secara etimologi kata Bhuta Yajña berarti persembahan yang tulus dan ikhlas kepada unsur-unsur alam yang telah diadakan, dan secara harfiah dapat diartikan bahwa Bhuta Yajña adalah persembahan secara tulus dan ikhlas yang ditujukan kepada ciptaan Sang Hyang Widhi baik secara niskala dan skala yang hidup bersama dengan manusia.

Sebagai salah satu bentuk upakara Bhuta Yajña yang paling sering dipergunakan dan paling banyak orang mampu membuatnya di kalangan rumah tangga adalah segehan manca warna. Meskipun dalam desa, kala, dan patranya berbeda-beda namun dari segi esensi setiap upakara memiliki makna yang sama. Struktur segehan manca warna dapat dilihat pada gambar 1 dan 2 .

Menurut Niken Tambang Raras (2009:48) bahan-bahan atau perlengakapan pembuatan segehan manca warna adalah upakara jenis segehan yang menggunakan daun pisang sebagai alasnya menggunakan daun pisang dalam berbagai daerah memiliki kebiasaan yang berbeda-beda biasanya dua lembar daun pisang hanya di bentangkan membentuk persegi dengan setiap sudut yang dihaluskan ataupun ataupun janur yang dibentuk segitiga (tangkir) dan ditumpuk bolak balik. Di bagian bawah dari pada alas tersebut di beri tangkih untuk tempat lauk dan di bagian atas diberikan porosan dan bunga. Selain itu terdapat juga nasi dengan warna hitam, putih, merah dan kuning serta brumbun yakni percampuran dari keempat warna tersebut. Segehan ini dihaturkan kepada Kala Buchara / Buchari (Bhuta Kala) supaya tidak mengganggu. Penyajiannya diletakkan di bawah / sudut- sudut natar Merajan / Pura atau di halaman rumah dan di gerbang masuk bahkan ke perempatan jalan (Putra. 1984:23).

Mengenai waktu penyajiannya bisa dilakukan tiap hari, atau hari- hari tertentu sesuai kebiasaan dan rerainan. Bahan utamanya adalah nasi berwarna beberapa kepal peletakannya, sebagai berikut hitam di utara, putih di timur, merah di selatan, kuning di barat, brumbun di tengah. (http://www.babadbali.com/canangsari/banten/segehan. htm).

\section{Estetika dalam Segehan Manca Warna}

Dilihat dari pengertian estetika di atas rasanya tidaklah berlebihan bila dikatakan bahwa Segehan Manca War$n a$ termasuk indah terlebih lag i apabila dilihat dari sisi pengamat seni itu. Tidak hanya sekadar indah, tetapi juga sarat dengan makna dan terlebih lagi bahwa estetika Hindu memiliki konsep Siwam, Satyam, dan Sundaram.

Sesuatu dapat dikatakan indah apabila mengandung unsur-unsur estetika, yakni (1) Wujud atau rupa (appearance) yang meliputi bentuk (form) atau unsur yang mendasar dan susunan atau struktur, (2) Bobot atau isi (substance) yang meliputi suasana (mood), gagasan (idea), dan pesan (message), dan (3) Penampilan, penyajian (presentation) yang meliputi bakat (talent), Ketrampilan (skill), dan sarana atau media, (Djelantik. 2004:17). Lebih lanjut lagi akan dianalisis estetika pada segehan manca warna berdasarkan ketiga unsur tersebut.

Komposisi merupakan penataan unsur-unsur yang membentuk keindahan suatu karya. Komposisi keindahan "segehan manca warna" adalah menata atau menyusun bahan pembentuk segehan manca warna itu sendiri, seperti: bentuk dari daun pisang, besar-kecilnya kepelan nasi berwarna dan ituk-ituknya.

1. Keseimbangan. Penataan unsur-unsur "segehan manca warna" dengan memperhatikan keseimbangan antara bagian kiri dan kanan dengan menerapkan keseimbangan simetris, yaitu bagian kiri dan kanan diusahakan unsur-unsurnya memiliki bentuk dan ukuran, yang sama. Hal ini dilakukan agar "segehan manca warna" tidak berkesan berat sebelah.

2. Kesatuan. Penataan unsur-unsur "segehan manca warna" agar berkesan suatu keutuhan bentuk. Unsur yang satu mendukung unsur yang lainnya sehingga tidak ada kesan yang lepas atau terpisah antara bagian-bagian dari "segehan manca warna" itu sendiri. 
Penataan ini perlu dilakukan agar pandangan orang terhadap "segehan manca warna" terfokus pada keutuhan bentuk "segehan manca warna".

3. Irama. Penataan unsur-unsur "segehan manca warna" berdasarkan irama untuk menimbulkan keharmonisan bentuk "segehan manca warna". Penataan ini dapat dilakukan dengan mengatur gradasi bentuk, ukuran dan warna unsur, misalnya dari bentuk kepel-kepel nasinya yang sama besar ataupun kecilnya, dan lagi warnanya yang cerah.

4. Proporsi. Proporsi merupakan perbandingan dalam penataan unsur-unsur pembentuk "segehan manca warna" termasuk ketepatan penempatan posisi dari masing-masing bagian-bagian dari "segehan manca warna", seperti penempatan nasi berwarna dengan kepal yang sesuai besarnya, alas daun pisang yang sama ukurannya, dan porosan serta tangkih tajuh, ituk-ituk dengan bunga yang ada di atas, dilengkapi dengan lauknya.

\section{Makna Segehan Manca Warna}

Bagi masyrakat Hindu di Bali, Bhūta Kala itu dibayangkan sebagai makhluk-makhluk halus dengan rupa yang menakutkan dan sering menimbulkan gangguan serta bencana, tetapi bila diperhatikan (diberi korban/diberi persembahan) mereka akan membantu serta melindungi (Putra, 1984:3).

Menurut sumber purwaka bhumi dan purwa bhumi kemulan, dalam buku Upakara Bhuta Yajña, Ny. I Gusti Agung Mas Putra (1984:7-8) dijelaskan bahwa Ida Sang Hyang Widhi wasa telah menciptakan Pañca Dewata, masing-masing diberi nama:

a. Sang Kursika berwarna putih, kemudian menjadi Bhuta Dengen atau disebut juga Bhuta Janggitan berwujud Yaksa dan bertempat di arah timur.

b. Sang Gargha berwarna merah, kemudian menjadi Bhuta Abang disebut pula sang Bhuta Langkir berwujud Mong bertempat di arah selatan.

c. Sang Metri berwarna kuning, menjadi Bhuta Kuning atau disebut pula Bhuta Lembukaniya yang berwujud ular atau naga bertempat di arah barat.

d. Sang kurusiya berwarna hitam, menjadi Bhuta Ireng disebut juga Sang Bhuta Taruna berwujud buaya bertempat di arah utara.

e. $\quad$ Sang Pretanjala berwarna Brumbun (Viswa-Warna) kemudian menjadi Bhuta Manca Warna yang disebut juga Sang Bhuta Tiga Sakti bertempat di arah tengah.

Selain itu Sang Hyang Widhi juga menciptakan satu unsur Pradana disebut Canting Kuning atau Bhatari Uma, bertempat di arah tengah dan dalam wujud Bhuta disebut Dewi Durga. Dengan demikian maka di arah tengah ditempati oleh unsur Pradana dan unsur Purusa, yang disebut Uma Pretan Jala.

Segehan sebagai sebuah wujud ritual dalam masyarakat
Hindu di Bali memiliki bentuk yang beraneka ragam, sesuai dengan keperluan. Segehan adalah kurban atau ritual persembahan yang bukan bertujuan untuk mengungkapkan rasa syukur. Secara umum, fungsi segehan ada empat, yaitu 1) untuk sarana persembahan, 2) untuk permohonan, 3) untuk penghormatan, dan 4) untuk membayar hutang (Dewa Rna).

Wujud ritual dalam hal ini adalah rupa atau bentuk ritual segehan. Wujud ritual segehan itu bermacam-macam sesuai dengan tujuan pembuatan dan permohonannya. Bagaimanapun wujudnya, bahan utamanya tidaklah berbeda, yaitu nasi atau sega. Yang berbeda-beda antara di suatu daerah dan daerah lainnya adalah alas yang digunakan. Pada beberapa daerah menggunakan daun pisang sebagai alas, dan di daerah yang lainnya menggunakan janur, slepan. Selain itu, ada juga masyarakat yang menggunakan daun pohon dadap atau daun pohon yang lain sebagai alasnya.

Seperti telah dijelaskan di depan, segehan adalah wujud ritual kurban yang ditujukan kepada para Bhüta Kala beserta pengikut-Nya. Sebagai sebuah ritual kurban, segehan adalah wujud ritual berupa nasi yang dibentuk sedemikian rupa yang dilengkapi dengan lauk bawang, jahe, darah, dan sebagainya. Sebagai minumannya adalah lima jenis cairan, yaitu 1) arak, 2) tuak, 3) b ěr ěm, 4) darah, dan 5) air.

Hal itu sejalan dengan pendapat Dhavamony (2002: 214) yang mengatakan bahwa, upacara kurban adalah persembahan ritual berupa makanan atau minuman atau binatang, sebagai konsumsi bagi suatu mahluk supernatural. Segehan sebagai sebuah wujud ritual juga dilengkapi dengan beberapa peralatan yang lain seperti, lauk (bawang merah, jahe, dan jeroan mentah), minuman (arak, berem 'air tape', air, tuak 'nira', dan darah), api, dan canang. Masing-masing perlengkapan segehan itu memiliki makna sendiri-sendiri. Adapun maknanya adalah sebagai berikut.

\section{Lauk}

Bawang merah, jahe, dan jeroan mentah adalah lauk yang selalu menyertai ritual segehan. Bawang merah yang memiliki bau dan rasa yang sangat tajam atau amis; jahe yang memiliki rasa sepat dan pahit; dan jeroan mentah atau isi perut, dalam kepercayaan masyarakat Hindu di Bali adalah kesukaan bhuta kala. Sěgala sesuatu yang berbau menyengat dan amis seperti tersebut di atas, menurut keyakinan umat Hindu disenangi oleh para bhūta kala.

Bawang merah yang berbau amis itu juga sering digunakan oleh masyarakat sebagai penangkal leyak dengan cara dioleskan pada ubun-ubun bayi atau balita. Maksudnya adalah agar leyak tersebut tidak mengganggu si bayi karena sudah cukup puas dengan menjilat bau bawang merah itu. Untuk menolak mara bahaya secara umum, bawang merah itu bisa dioleskan diberbagai tempat, misalnya di badan 
orang dewasa , di atas pintu kamar, dan di sebelah kiri atau kanan pintu rumah.

Garam dalam kehidupan masyarakat memiliki manfaat yang sangat banyak. Garam memiliki peranan yang sangat penting dalam kehidupan manusia. Benda tersebut sangat akrab dengan kehidupan manusia, sampai-sampai digunakan sebagai pepatah yang berbunyi, bagaikan sayur tanpa garam, yang bermakna 'hambar'. Dalam hubungannya dengan segehan, garam juga mengandung makna penyedap rasa persembahan. Dengan garam itu diharapkan segehan yang ditujukan kepada bhuta kala itu menjadi lebih enak rasanya, sehingga mereka terlena dan tidak ingat lagi dengan hal-hal yang lain.

\section{Minuman}

Minuman (arak, berem 'air tape', air, tuak 'nira', dan darah), yang digunakan sebagai pelengkap segehan dikenal dengan tetabuhan. Kata tetabuhan itu sendiri berasal dari kata tabuh yang berarti 'tabur', 'siram'. Hal itu sesuai dengan cara persembahan minuman itu, yaitu dengan cara disiramkan pada segehan.

Bhūta kala dalam kepercayaan masyarakat Hindu diandaikan sebagai sosok yang mengerikan, menyeramkan, senang mabuk-mabukan, dan sebagainya yang memiliki sifat tidak baik. Berdasarkan keyakinan itu, mereka memandang perlu untuk memanjakannya dengan berbagai minuman keras yang memabukkan. Arak, berem 'air tape', tuak 'nira', dan darah adalah jenis-jenis minuman yang memabukkan. Dengan minuman (tetabuhan) tersebut di tambah dengan air, diharapkan para bhuta kala sudah merasa puas dan tidak mengganggu manusia.

Persembahan darah dalam ritual Hindu dilaksanakan dengan berbagai cara, misalnya dengan mengadu ayam (tajen), dengan darah ayam atau babi yang langsung ditaruh pada segehan, dan dengan menyembelih anak ayam atau itik saat ritual segehan. Persembahan darah dengan penyembelihan anak ayam atau itik dikenal dengan istilah penyambléh. Dalam praktek sehari-hari, wujud ritual minuman yang berupa darah sering diganti dengan telor. Masyarakat yakin bahwa telor memiliki makna yang sama dengan darah. Pemekaian telor sebagai pengganti darah dapat diljumpai dalam wujud ritual segehan agung.

\section{Api}

Api dalam keyakinan umat Hindu memiliki peranan dan makna yang sangat penting. Dalam hubungannya dengan kegiatan ritual, api dapat berwujud dupa dan api takep 'api yang dibuat dalam dua buah sabut kelapa'. Dupa atau api yang digunakan dalam ritual itu mengandung makna sebagai lambang Dewa Brahma sebagai saksi atas ritual yang dilakukan. Brahma adalah Dewa Api yang memiliki fungsi dan peranan sebagai penerang jiwa orang yang menggunakannya. Asap yang ditimbulkan oleh dupa atau api takep yang membumbung ke udara diyakini sebagai penghantar ritual kepada para para dewa dan bhuta kala. Api yang memiliki sifat yang sama dengan matahari juga diyakini sebagai simbol Dewa Matahari yang dalam masyarakat Hindu dikenal dengan Sang Hyang Surya atau Sang Hyang Tigawelas atau Sang Hyang Triyodasasaksi. Wujud ritual dupa diandaikan bahwa dalam ritual tersebut telah hadir Sang Hyang Triyodasasaksi 'tiga belas unsur Tuhan sebagai saksi' yang menyaksikan ritual sehingga menjadi sah adanya.

\section{Canang}

Kata canang berasal dari Bahasa Jawa Kuno yang berarti 'sirih'. Sirih yang di dalamnya dilengkapi dengan kapur dan pinang yang kemudian dikenal dengan porosan adalah unsur utama dari canang. Kalau sebuah canang itu tidak berisi porosan dianggap belum bernilai keagamaan. Porosan itu adalah lambang Tuhan sebagai Tri Murti. Pinang yang berwarna merah adalah lambang Dewa Brahma sebagai pencipta, sirih yang berwarna hijau adalah lambang Dewa Wisnu sebagai pemelihara, dan kapur yang berwarna putih adalah lambang Dewa Siwa sebagai pemusnah (Titib, 2001: 144). Pemujaan Tuhan sebagai pencipta, pemelihara, dan pemusnah bertujuan untuk memohon kepada-Nya agar tercipta sesuatu yang memang patut tercipta, terpelihara sesuatu yang memang semestinya terpelihara, dan bergantinya atau leyapnya sesuatu yang mesti harus berganti atau lenyap (Wiana, 2000:32; 2001: 9).

\section{PENUTUP}

Keindahan (estetika) hasil dari kreativitas manusia baik sengaja atau tidak, pada prinsipnya adalah untuk memenuhi kepuasan bathin atau rohani bagi pembuat karya itu sendiri dan bagi masyarakat penikmat. Kehidupan manusia dalam kesehariannya selalu memerlukan keindahan untuk memenuhi kepuasan bathinnya, baik yang diperoleh dari keindahan alami maupun keindahan karya manusia.

Kesucian (shiwam) pada intinya menyangkut nilai-nilai ketuhanan yang juga mencakup Yajña dan taksu. Umat Hindu, seperti yang terlihat di Bali, memiliki pandangan estetik yang diikat oleh nilai-nilai spiritual ketuhanan sesuai dengan ajaran agama Hindu. Kebenaran (satyam) mencakup nilai kejujuran, ketulusan, dan kesungguhan. Keseimbangan (sundaram) yang mencakup persamaan dan perbedaan dapat terefleksi dalam beberapa dimensi.

Dari uraian mengenai segehan di atas dan kriteria estetika, maka keindahan pada Segehan manca warna terletak pada bentuk, komposisi dan proporsisi, serta makna atau pesan yang terdapat pada upakara tersebut.

Ukuran yang pas antara kepalan nasi dengan besarnya alas serta pelengkap yang melengkapi segehan manca warna yang tetap harus sesuai dengan pakem yang sudah ada sehingga menjadi suatu bentuk upakara yang juga memi- 
liki makna dan pesan, tetapi juga indah dipandang mata yang nantinya akan membuat hati ini menjadi langö atau kelangöan.

\section{DAFTAR RUJUKAN}

Djelantik, A.A.M. (2008), Estetika Sebuah Pengantar (cetakan Keempat), Masyarakat Seni Pertunjukan Indonesia (MSPI), Jakarta.

Puspa, Ida Ayu Tary. (Maret 2019), “Ardanareswari dalam Upacara Yajña di Desa Pakraman Renon Denpasar (Perspektif Teologi Gender)", dalam Jurnal Penelitian Sejarah dan Nilai Tradisional Volume 26 Nomor 1 Maret 2019, Halaman 39-56, Balai Pelestarian Nilai-nilai Budaya, Denpasar

Puspa, Ida Ayu Tary. (2019), "Peranan Seni Sastra dalam Pengmbangan Karakter: Kajian Cerita Ni Diah Tantri" dalam Konferensi Sastra Bahasa dan Budaya, Halaman 170-175.

Puspa, Ida Ayu. (Maret 2015), "Kwangen dalam Upacara Ngeringkes Serangkaian Upacara Ngaben (Perspektif Estetika Hindu)" dalam Pangkaja Volume 17 Nomor 1 Maret 2015. Halaman 35-44, Program Pascasarjana Institut Hindu Dharma Negeri, Denpasar.

Putra, Ny, I.G. Ag. Mas. (1984), Upakara Bhuta Yajña, Denpasar.

Raras, Niken Tembang. (2009), Upakara dan Banten Jilid 1, Paramita, Surabaya.

Wijayaananda, Ida Pandita Mpu. (2003), Tetandingan Lan Sorohan Bebantenan, Paramita, Surabaya.

Yudha, Ida Bagus Gde Triguna. (2003), Estetika Hindu dan Pembangunan Bali, Program Magister Ilmu Agama dan Kebudayaan Universitas Hindu Indonesia Bekerja Sama Dengan Widya Dharma, Denpasar. 